\title{
PENGARUH PENAMBAHAN KOSUBSTRAT PADA BIODEGRADASI CRUDE OIL
}

\author{
Any Juliani; Annisa Nur Lathifah dan Winda Aisyah Nurdin \\ Jurusan Teknik Lingkungan, Universitas Islam Indonesia, Jl. Kaliurang KM 14,5 Yogyakarta \\ E-mail : any.juliani@uii.ac.id
}

\begin{abstract}
Abstrak
Kegiatan penambangan minyak bumi tidak hanya dilakukan oleh perusahaan-perusahaan besar, tetapi juga oleh masyarakat secara tradisional. Potensi pencemaran lingkungan yang ditimbulkan oleh kegiatan penambangan rakyat ini menjadi lebih tinggi karena pengelolaannya yang tradisional. Salah satu jenis pencemaran yang ditimbulkannya misalnya adalah tanah atau perairan yang tercemar oleh minyak bumi (crude oil) pada saat berlangsungnya kegiatan penambangan. Salah satu upaya untuk dapat mengatasinya adalah dengan bioremediasi. Bioremediasi merupakan teknologi pengolahan pencemar dengan memanfaatkan aktivitas mikroba, terutama dari golongan bakteri. Bioremediasi tersebut harus melibatkan bakteri yang memiliki kapasitas metabolic untuk melakukan biodegradasi terhadap crude oil tersebut. Crude oil sendiri pada dasarnya merupakan senyawa hidrokarbon yang merupakan sumber karbon yang kaya bagi mikroba. Namun demikian, biodegradasi crude oil relative lebih sulit dilakukan karena karakteristiknya yang merupakan senyawa dengan berat molekul dan ukuran yang besar. Oleh karena itu penambahan kosubstrat yang lebih sederhana dapat dilakukan untuk membantu biodegradasi terutama pada tahap awal proses. Penelitian ini dilakukan untuk mengetahui pengaruh penambahan kosubstrat dalam hal ini glukosa terhadap biodegradasi crude oil. Penelitian dilakukan dalam media cair dengan bioaugmentasi melalui penambahan inoculum bakteri yang diisolasi dari tanah yang dikondisikan terhadap crude oil dalam beberapa variasi reactor. Indikasi terjadinya biodegradasi diperiksa melalui pengukuran terhadap parameter Total Petroleum Hydrocarbon (TPH) dan Total Plate Count (TPC). Hasil penelitian menunjukkan bahwa penambahan kosubstrat glukosa memberikan pengaruh positif terhadap penurunan TPH. Penurunan TPH tertinggi setelah 28 hari adalah sebesar 25,3 \% yang diberikan oleh reactor dengan penambahan kosubstrat serta konsentrasi crude oil awal sebesar $8.1 \%$. Sementara itu reactor tanpa penambahan penambahan glukosa, penurunan TPH-nya hanya mencapai 19,4 $\%$.
\end{abstract}

Kata kunci: isolasi, biodegradasi, crude oil, bioremediasi, kompos, Total Petroleum Hydrocarbon

\begin{abstract}
Traditional oil mining is still practiced in some oil rich areas in Indonesia. The potential environmental pollution caused by this traditional mining practice is higher than that of established oil company. One type of pollution caused by this activity is oil-spill contaminated soil or water. Bioremediation is one alternative technology that can be applied to solve the problem. Bioremediation is contaminant remediation technology by using microbe activities, especially bacteria. Bacteria involved in bioremediation process should possess metabolic capacity to biodegrade the particular oil based contaminant. Crude oil basicly composed of hydrocarbon which is actually rich carbon source for microbe. However, crude oil biodegradation is relatively more difficult to occur due to some of its characteristic such as high molecular weight of its polycyclic aromatic fraction or its limited availability to microbes. Therefore, the addition of simple cosubstrate can be undertaken to stimulate or enhance biodegradation especially at the initial stage. The purpose of this study was to find out the effect of addition of glucose as cosubstrate in crude oil biodegradation. Study was conducted in liquid medium in various reactor compositions. Bioaugmentation was done through addition of bacterial inoculum isolated from soil conditioned with crude oil. Total Petroleum Hydrocarbon/TPH and Total Plate Count/TPC were used to indicate and measure biodegradation activity. The results showed that addition of glucose gave positive effect to reduce TPH. Highest TPH reduction after 28 days was 25,3\% performed by reactor with initial TPH concentration of $8.1 \%$. Reactor without glucose addition gave only $19.4 \%$ of TPH reduction.
\end{abstract}

Key words: crude oil, bioremediation, total petroleum hydrocarbon

Dikirim/submitted: 3 April 2016

Diterima/accepted: 30 April 2016 


\section{PENDAHULUAN}

Bioremediasi merupakan proses pemanfaatan kemampuan metabolic mikroorganisme untuk penanganan pencemar. Proses ini semakin banyak digunakan karena kemudahan, lebih efisien serta cost-effective (Capello, 2015). Salah satu aplikasi teknologi bioremediasi diantaranya adalah untuk pemulihan lingkungan akibat pencemaran minyak bumi baik yang berasal dari aktivitas pertambangan maupun pemurniannya. Aktivitas pertambangan maupun pemurnian minyak bumi tersebut tidak hanya dilakukan oleh perusahaan-perusahaan besar tetapi juga oleh masyarakat melalui kilang-kilang rakyat. Salah satunya dilakukan di Desa Talang Sungaiangit, Kecamatan Babat Toman, Kabupaten Musi Banyuasin, Propinsi Sumatera Selatan. Pengelolaan secara tradisional menjadikan risiko timbulnya pencemaran yang lebih tinggi dibandingkan kilang minyak modern yang dikelola perusahaanperusahaan minyak besar.

Bioremediasi untuk pemulihan pencemaran akibat kegiatan penambangan minyak bumi harus melibatkan mikroba yang memiliki kapasitas metabolic untuk dapat melakukan biodegradasi terhadap senyawa minyak bumi tersebut. Bakteri merupakan jenis mikroba yang paling penting dan banyak terlibat dalam biodegradasi minyak bumi. Termasuk dalam bakteri ini adalah yang berasal dari genus Pseudomonas, Alcanivorax, Acinetobacter, Microccocus, Corynebacteria, Nocardia dan Rhodococcus (Mahjoubi, et.al, 2013). Golongan bakteri tersebut disebut hidrokarbonoklastik. Beberapa jenis bakteri bahkan menjadikan senyawa hidrokarbon sebagai satu-satunya sumber karbon (Das, et.al., 2010). Minyak bumi/crude oil sendiri pada dasarnya merupakan senyawa hidrokarbon yang merupakan sumber karbon yang kaya bagi mikroba. Namun demikian, biodegradasi crude oil relative lebih sulit dilakukan karena beberapa sebab (Juliani dan Rahman, 2011). Oleh karena itu, biodegradasi sering terjadi melalui kometabolisme, dimana bakteri memerlukan sumber karbon lain yang lebih mudah didegradasi. Berdasarkan mekanisme ini, penambahan kosubstrat pada reactor atau lahan yang terkontaminasi dapat memberikan kontribusi pada proses degradasi (Vasconcelos, 2013).

Penelitian ini dilakukan untuk mengetahui pengaruh penambahan kosubstrat dalam hal ini glukosa terhadap biodegradasi crude oil. Penelitian dilakukan dalam media cair dengan bioaugmentasi melalui penambahan inoculum bakteri yang diisolasi dari tanah yang dikondisikan terhadap crude oil dalam beberapa variasi reactor. Hasil penelitian dapat menjadi salah satu acuan dalam merancang proses bioremediasi yang tepat untuk mengatasi masalah pencemaran lingkungan akibat kegiatan penambangan minyak bumi rakyat di Indonesia. 


\section{METODE PENELITIAN}

Penelitian dilakukan dengan mengikuti alur sebagai berikut:

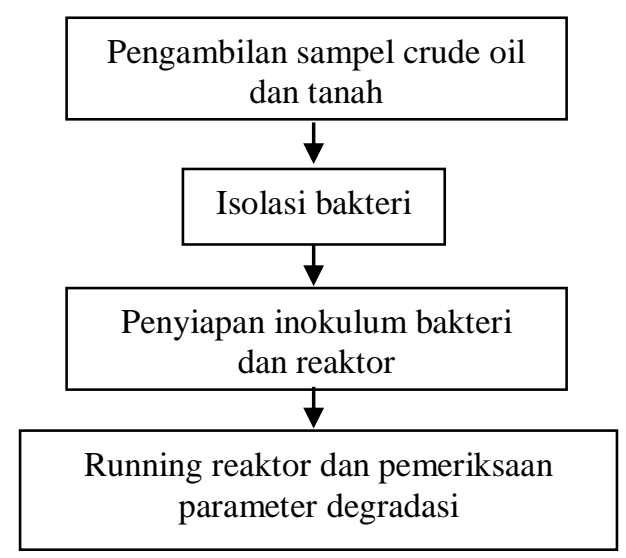

Gambar 1. Alur penelitian

\subsection{Pengambilan sampel crude oil}

Sampel crude oil diambil dari lapangan pemboran minyak bumi rakyat milik warga Desa Talang Sungaiangit, Kecamatan Babat Toman, Kabupaten Musi Banyuasin, Propinsi Sumatera Selatan.

\subsection{Isolasi bakteri}

Bakteri yang digunakan untuk penelitian berasal dari tanah yang dikondisikan terhadap crude oil. Tanah yang digunakan adalah tanah yang berasal dari area perbengkelan sekitar Kampus Universitas Islam Indonesia yang sudah tercemar oli. Tanah yang sudah disaring dicampur dengan crude oil dengan perbandingan tanah dan crude oil 70 : 30. Campuran dibiarkan selama 10 hari dalam suhu ruangan dan secara teratur dilakukan pengadukan. Selanjutnya dilakukan isolasi dilakukan dengan metode pour plate. Media yang digunakan adalah media Nutrient Agar/NA dengan komposisi per liter air suling adalah $1 \mathrm{~g}$ ekstrak sapi, $2 \mathrm{~g}$ ekstrak yeast, $5 \mathrm{~g}$ peptone, $5 \mathrm{~g}$ NaCL, dan $15 \mathrm{~g}$ bacto agar. Inokulan diinkubasi selama 24-48 jam. Selanjutnya dilakukan pemurnian kultur untuk mendapatkan isolat murni (pure culture). 


\subsection{Penyiapan inokulum bakteri dan reactor.}

Inokulum bakteri untuk reactor berasal dari seluruh isolat (mixed culture) yang ditumbuhkan dalam media Nutrient Broth/NB. Komposisi Media NB sama seperti NA tanpa penambahan bacto agar. Inokulum dipindahkan ke reaktor penelitian pada awal fase stasioner yang diketahui melalui pemeriksaan Optical Density OD) menggunakan spektrofotometer pada panjang gelombang $600 \mathrm{~nm}$. Reaktor yang digunakan dalam penelitian ini berjumlah 6 buah yang terdiri dari reaktor uji dan reaktor kontrol. Variasi perlakuan pada reaktor disajikan dalam tabel 1 berikut

Tabel 1. Variasi Reaktor

\begin{tabular}{lc}
\hline \multicolumn{1}{c}{ Reaktor } & Variasi \\
\hline Kontrol 1 & $5 \%$ crude oil \\
Kontrol 2 & $5 \%$ crude oil + glukosa \\
Reaktor $1 \mathrm{a}$ & $5 \%$ crude oil + inokulum \\
Reaktor $1 \mathrm{~b}$ & $10 \%$ crude oil + inokulum \\
Reaktor $2 \mathrm{a}$ & $5 \%$ crude oil + glukosa + inokulum \\
Reaktor $2 \mathrm{~b}$ & $10 \%$ crude oil + glukosa + inokulum \\
\hline
\end{tabular}

\subsection{Running reactor dan pemeriksaan parameter degradasi}

Parameter yang diukur selama penelitian adalah pH, Total Petroleum Hydrocarbon (TPH), dan Total Plate Count (TPC). Pemeriksaan dilakukan setiap 7 hari sekali selama 28 hari. Pengujian parameter $\mathrm{pH}$ dilakukan dengan menggunakan metode potensiometri yang mengacu pada SNI 06-6989.11-2004, sedangkan pengujian Total Plate Count (TPC) dilakukan dengan menggunakan metode pour plate. Parameter Total Petroleum Hydrocarbon (TPH) diuji dengan prinsip gravimetric menggunakan metode yang dikembangkan oleh Greenberg, 1992 dalam Juliani, 2011.

\section{HASIL DAN PEMBAHASAN}

Setelah inkubasi selama 3 hari, berhasil diisolasi 12 isolat dari sampel tanah yang telah dikondisikan dengan crude oil. Sediaan inokulum untuk reactor berasal dari konsorsium ke-12 isolat bakteri tersebut. Kurva pertumbuhan bakteri disajikan dalam Gambar 2 berikut. 


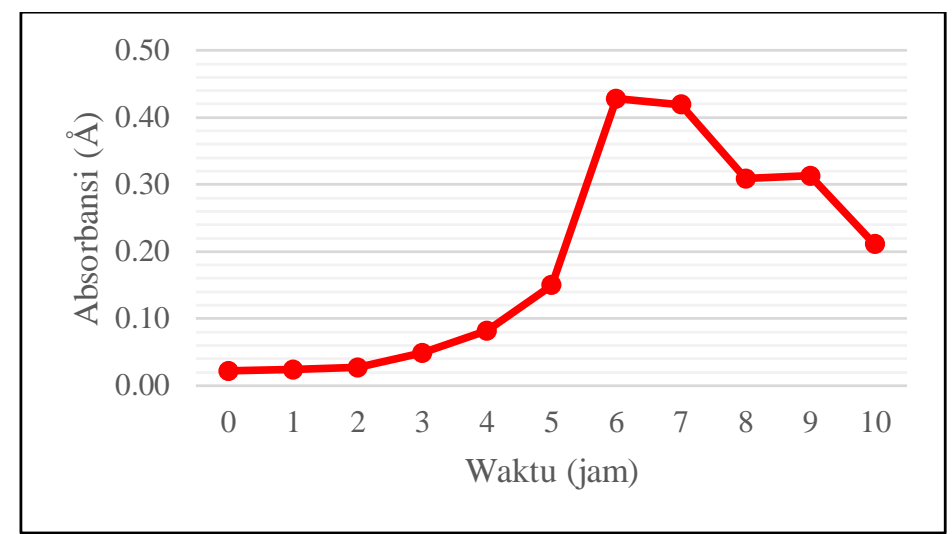

Gambar 2. Kurva Pertumbuhan Bakteri

Inokulum dipindahkan ke reactor penelitian setelah mencapai fase logaritmik atau di awal fase stasioner. Berdasarkan grafik kurva pertumbuhan di atas, pemindahan tersebut dilakukan setelah 6 jam. Hasil analisis sifat kimia crude oil menunjukkan nilai konsentrasi c-organik yang sangat tinggi yaitu mencapai 50,60\%. Hal ini terjadi karena pada dasarnya crude oil merupakan senyawa hidrokarbon yang komposisi utamanya adalah karbon dan hidrogen.

Tabel 2. Hasil Analisis Sampel Crude Oil

\begin{tabular}{clcc}
\hline No & Parameter Analisis & Satuan & Konsentrasi \\
\hline 1 & Carbon organik & $\%$ & 50,60 \\
2 & Kadar air & $\%$ & 0,0 \\
3 & $\mathrm{pH}$ & $\mathrm{H}_{2} 0\left(29,7^{\circ} \mathrm{C}\right)$ & 6,79 \\
\hline
\end{tabular}

Hasil pemeriksaan terhadap parameter indikator degradasi selama 28 hari disajikan dalam gambar 3-6 berikut. Kedua reaktor kontrol menunjukkan penurunan TPH yang dapat disebabkan oleh dua hal. Pertama, penurunan TPH terkait dengan sifat fisik senyawa hidrokarbon minyak bumi. Fraksi rantai pendek hidrokarbon dalam senyawa minyak bumi bersifat volatil. Volatilisasi selama proses ini menyebabkan terjadinya penuruhan TPH. Penyebab kedua adalah kemungkinan biodegradasi dilakukan oleh mikroba indigen dari crude oil itu sendiri. Li et.al (2013) mengungkapkan bahwa mikroba indigen lebih banyak digunakan dalam proses pengolahan lahan tercemar karena lebih sesuai dengan lingkungan tercemar tersebut serta kemungkinannya lebih kecil untuk menimbulkan inhibisi proses. Indikasinya terlihat dari penurunan TPH yang lebih baik pada reaktor kontrol 2 yang diberi tambahan kosubstrat glukosa. Namun demikian, perlakuan bioaugmentasi dengan penambahan inokulum bakteri 
tanah terkondisikan crude oil, memberikan pengaruh positif pada proses degradasi. Hal ini terlihat dari performa reaktor A dan B yang menunjukkan penurunan TPH yang lebih baik dari reaktor kontrol. Namun demikian, reaktor B menunjukkan performa penurunan TPH sebanyak 24-25\%, lebih baik dari reaktor A yang hanya 17-19\%. Hal ini menunjukkan pengaruh positif penambahan kosubstrat glukosa pada proses biodegradasi.

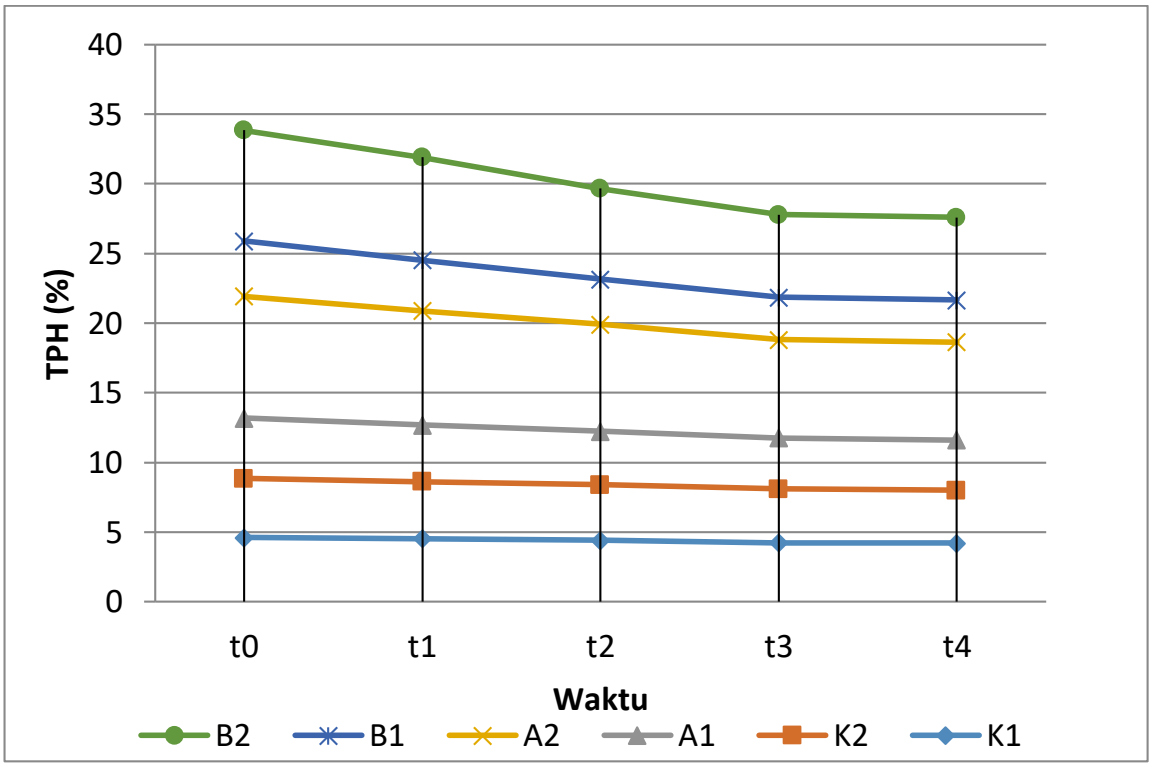

Gambar 3. Profil TPH selama 28 hari

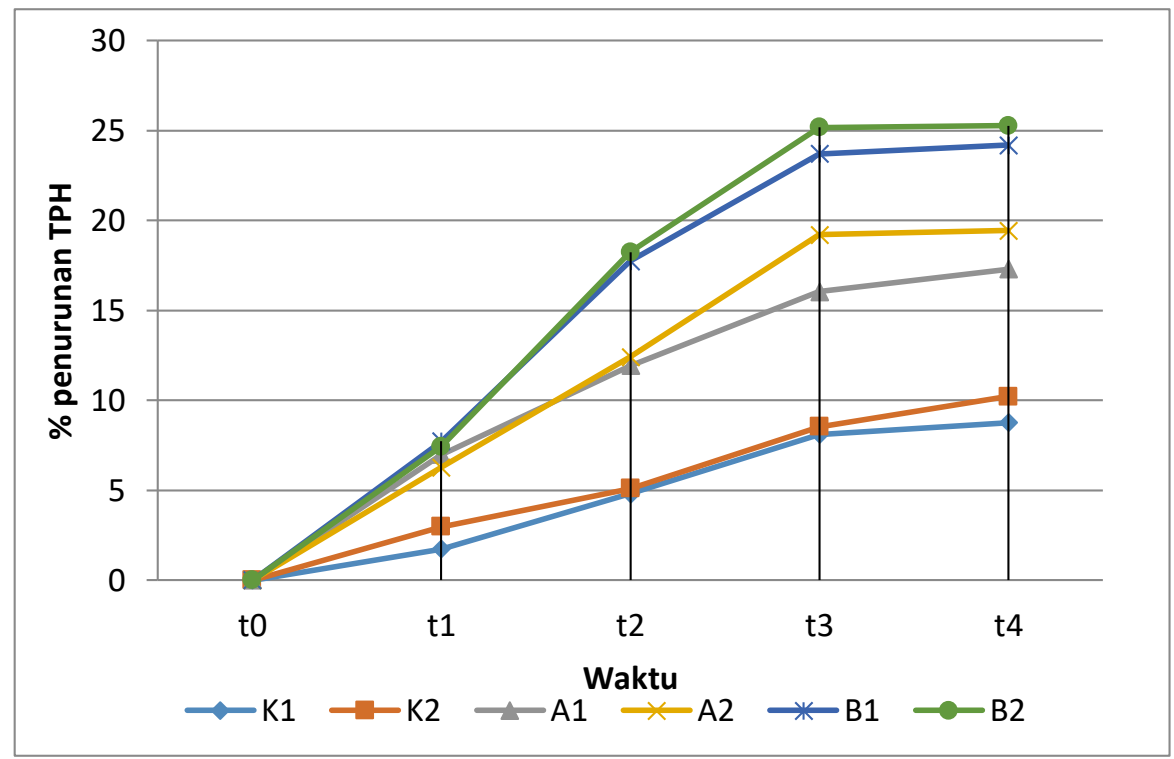

Gambar 4. Profil penurunan TPH selama 28 hari 
Nilai TPH sampai hari ke-21 menunjukkan laju penurunan antara $6-10 \%$, namun dari hari ke-21 sampai hari ke-28 penurunannya kurang dari $1 \%$. Hal ini sebanding dengan profil TPC-nya. Angka TPC terus meningkat sampai hari ke-21 namun menurun dari hari ke-21 sampai hari ke-28. Hal ini dapat terjadi akibat telah berkurangnya glukosa yang ada dalam reaktor atau juga akibat penurunan $\mathrm{pH}$ yang ditunjukkan pada gambar 6. Penurunan $\mathrm{pH}$ sampai mencapai 4 tidak disukai oleh mikroba yang hidup dalam reaktor sehingga beberapa mengalami kematian. Kematian mikroba ini menurunkan performa biodegradasi yang ditunjukkan dengan penurunan TPH yang sangat kecil. Penurunan $\mathrm{pH}$ disebabkan oleh pelepasan asam organic akibat degradasi hidrokarbon atau produksi polimer ekstraselular (Verma, et.al 2006 dalam Cerqueira et.al., 2011).

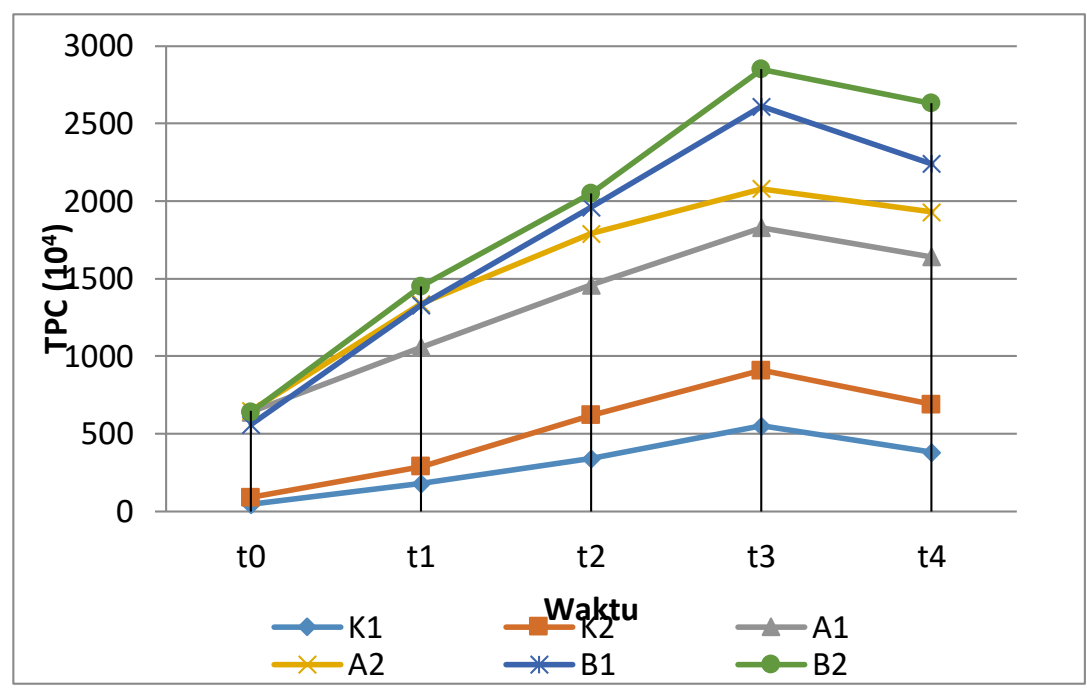

Gambar 5. Profil TPC selama 28 hari

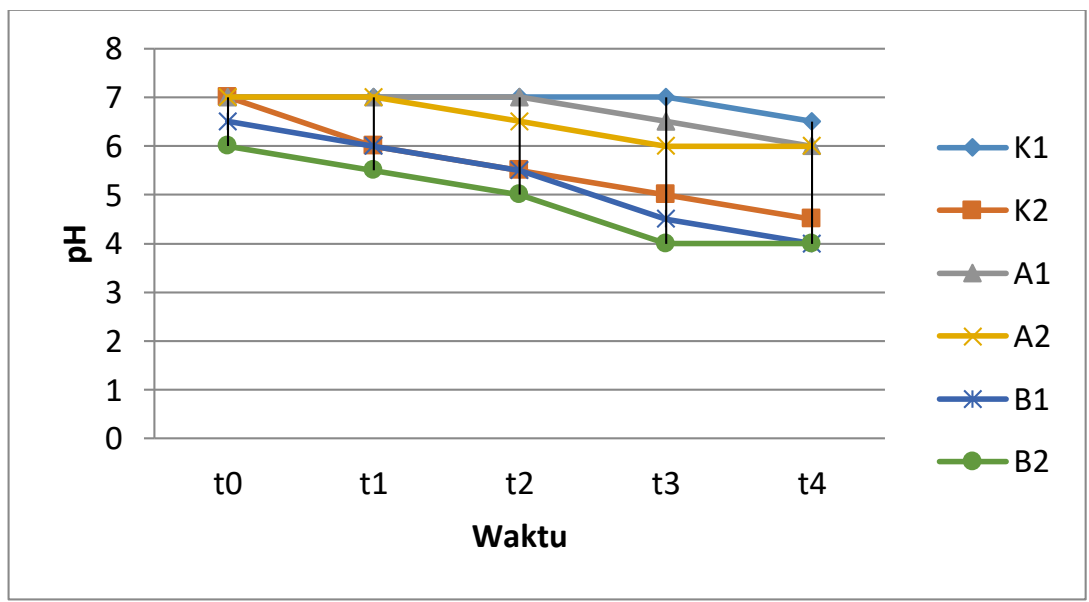

Gambar 6. Profil pH selama 28 hari 
Secara hipotetik, reaktor 1a dan 2a seharusnya menunjukkan penurunan TPH yang lebih baik karena mengandung kandungan crude oil yang lebih kecil. Namun ternyata penurunan TPH yang lebih baik secara konsisten ditunjukkan oleh reaktor $1 \mathrm{~b}$ dan $2 \mathrm{~b}$ yang memiliki proporsi crude oil lebih banyak. Hal ini dapat dikaitkan dengan aspek bioavailability dari senyawa kontaminan. Kemungkinan kedua yaitu adanya aktivitas dari bakteri crude oil yang membantu menurunkan TPH. Bakteri yang ada di dalam crude oil diduga memiliki kesamaan sifat dengan bakteri inokulasi yang dimasukkan ke dalam reaktor. Lasari (2010) menyatakan bahwa bakteri yang mampu mendegradasi senyawa hidrokarbon minyak bumi disebut dengan bakteri hidrokarbonoklastik. Dalam penelitian ini, bakteri inokulasi yang dimasukkan ke dalam reaktor merupakan bakteri yang dikultur dari tanah yang telah dikondisikan, yaitu tanah yang berada di sekitar bengkel yang merupakan tanah yang telah terkontaminasi oleh bahan-bahan yang berasal dari minyak bumi. Zhu, et al (2001) menyatakan bahwa pada lingkungan yang telah terkontaminasi minyak bumi dimungkinkan terdapat bakteri pendegradasi petroleum hydrocarbon yang secara alamiah bersaing dan berkonsorsia dengan mikroorganisme lainnya. Hal ini serupa dengan crude oil yang diambil dari kilang minyak milik warga lokal. Dimungkinkan terdapat bakteri hidrokarbonoklastik yang secara alami hidup di dalam crude oil dan mampu bertahan dalam kondisi lingkungan yang ekstrim. Sehingga ketika crude oil dipindahkan ke dalam reaktor penelitian, bakteri indigenous yang ada di dalam crude oil dapat tetap tumbuh bersama dengan bakteri yang diaugmentasikan.

\section{KESIMPULAN}

Kesimpulan dari penelitian ini adalah sebagai berikut

a. Penambahan glukosa memberikan pengaruh yang positif terhadap biodegradasi crude oil.

b. Penurunan TPH tertinggi sebesar $25.3 \%$ diberikan oleh reactor dengan proporsi crude oil lebih banyak yaitu sebanyak $7.7 \%$

\section{SARAN}

a. Penelitian dilakukan dalam jangka waktu lebih panjang sehingga efisiensi maksimum proses dapat diketahui.

b. Diperlukan variasi proporsi crude oil dan kosubstrat yang lebih banyak untuk dapat mengambil lebih banyak kesimpulan 
c. Diperlukan analisis Gas Chromatography (GC) untuk mendeteksi senyawa hidrokarbon di awal dan di akhir proses

\section{DAFTAR PUSTAKA}

Das, Nilanjana, Chandran, Preethy, (2010), Microbial Degradation of Petroleum Hydrocarbon Contaminants: An Overview. Biotechnology Research International. Volume 2011, Article ID 941810

Vasconselos, Ulrich, Oliveira, Fernando J. S, Franca, Francisca P., (2013), Raw Glycerol as Cosubstrate on The PAHs Biodegradation in Soil. SENRA Academic Publishers, British Columbia. Vol. 7, No.1, pp. 2203-2209

Juliani, A., Rahman, F., (2011), Bioremediasi Lumpur Minyak (Oil Sludge) dengan Penambahan Kompos sebagai Bulking Agent dan Sumber Nutrien Tambahan. Jurnal Sains dan Teknologi Lingkungan Vol. 3 No. 1 Hal. 1-18.

Zhu, Xueqing, Albert D. V, Makram T. S, and Kenneth L., (2001) Guidelines for the Bioremediation of Marine Shorelines and Freshwater Wetlands. Environmental Protection Agency : US.

Cappello, S., Rosario C, Santina S, Maria G, Renata D, Lucrezia G, Laura G, Giuseppe M, Michail M. Y., (2015), Bioremediation of oil polluted marine sediments: A bio-engineering treatment. International Microbiology. Vol.18. p 127-134.

Mahjoubi, M., Atef J, Amel G, Sonia B A, Ahlem J, Hanen C, Afef N, Abdellatif B, Nedra K and Ameur C., (2013), Hydrocarbonoclastic bacteria isolated from petroleum contaminated sites in Tunisia: isolation, identification and characterization of the biotechnological potential. New Biotechnology. Volume 30, Number 6.

Cerqueira, V. S., Emanuel B. H,, Franciele M, Marilene H. V, Flávio A.O.C, Maria C. R. P, Fátima M. B, (2011) Biodegradation potential of oily sludge by pure and mixed bacterial cultures. Bioresource Technology 102 11003-11010

Li Q, Wang M, Feng J, Zhang W, Wang Y, Gu Y, Song C, Wang S., (2013), Treatment of high-salinity chemical wastewater by indigenous bacteria - bioaugmented contact oxidation. Bioresource Technology 144 (2013) 380-386. 